\title{
OBSSERVATIONS ON THE ACIDIFYING CAPACITY OF THE EXPERIMENTALLY DISEASED KIDNEY IN THE DOG*
}

\author{
By PETER A. F. MORRIN,† NEAL S. BRICKER, $\ddagger$ S. W. KIME, JR.§ AND \\ CLAIRE KLEIN
}

\author{
(From the Department of Medicine, Renal Dizision, Washington University School of Medicine. \\ St. Louis, Mo.)
}

(Submitted for publication January 9, 1962; accepted February 22, 1962)

Metabolic acidosis is a characteristic feature of advanced renal disease. In most instances, however, the acidosis does not progress inexorably despite the continued acquisition of hydrogen ions from metabolic processes. The fact that arterial $\mathrm{pH}$ levels may remain stable for long periods of time implies that there is no net accession of hydrogen ions by the extracellular fluid, and this in turn suggests that the daily acid load is excreted despite a diminished population of functioning nephrons. Hence, the average basal rate of net hydrogen ion excretion per nephron must increase as the total population of nephrons decreases.

The present experiments were designed to evaluate the response of the experimentally diseased kidney in the dog to exogenous acid administration. The majority of experiments was performed on animals in which one kidney was diseased, and the opposite kidney was free of disease. In addition, several experiments were performed on a dog with bilateral pyelonephritis in which the disease was of unequal severity in the two kidneys. In all experiments, the acidifying capacity of the diseased, or more severely diseased kidney (designated as the experimental kidney) was compared with that of the contralateral organ (designated as the control kidney).

\section{METHODS}

Sixteen experiments were performed on 12 young adult female mongrel dogs weighing from 9.1 to $18.2 \mathrm{~kg}$.

* Supported by the National Institutes of Health (Grant A-2667), and the Department of the Army, Research and Development Branch (Contract no. DA-49007-MD-772). A preliminary report of these experiments was presented at the Fifty-second Annual Meeting of the American Society for Clinical Investigation, Atlantic City, N. J., May, 1960.

$\dagger$ American Heart Association Research Fellow.

$¥$ Established Investigator, American Heart Association. $\S$ USPHS Postdoctoral Research Fellow.
Unilateral pyelonephritis was produced in nine animals and unilateral aminonucleoside nephritis in two, using established techniques $(1,2)$. Bilateral pyelonephritis was produced in one dog which was studied on four separate occasions. Most animals were subjected to a preliminary bladder-splitting procedure (3) which permitted simultaneous collection of urine from each kidney, and studies were performed in the unanesthetized state. Three animals were studied after induction of pentobarbital anesthesia and urine was collected from catheters placed directly into the ureters. No difference in the experimental results was noted between these two groups. Glomerular filtration rate (GFR) was estimated by the exogenous creatinine clearance. Arterial blood was drawn throughout each clearance period by means of a polyethylene catheter inserted percutaneously into the femoral artery. All samples of blood and urine for $\mathrm{pH}$ and $\mathrm{CO}_{2}$ determinations were collected anaerobically under mineral oil. Brisk rates of urine flow were maintained by mannitol infusion in 13 experiments, and in three experiments sustained water diuresis was produced. Metabolic acidosis was induced by the daily administration of $4 \mathrm{~g}$ of ammonium chloride orally for periods ranging from 1 to 5 days. During the clearance measurements, sodium sulfate was infused at $200 \mu$ moles per minute to augment urinary acidity, and sodium phosphate buffered to $\mathrm{pH} 7.4$ was infused at $160 \mu$ moles per minute to provide adequate urinary buffer. Two experiments were performed on animals which had not received an acid load and had been rendered slightly alkalotic by the infusion of sodium bicarbonate. These studies were designed to measure the rate of ammonia excretion in the presence of an alkaline urine and neither sulfate nor phosphate was included in the sustaining infusions. Creatinine was measured by the method of Bonsnes and Taussky (4), $\mathrm{CO}_{2}$ by the method of Van Slyke and Neill (5), and ammonia by the method of Nathan and Rodkey (6). Plasma $\mathrm{pH}$ was measured anaerobically with a Beckman model $\mathrm{G}$ pH meter using a syringe-type glass electrode either at room temperature or at $37^{\circ} \mathrm{C}$. Values for the former samples were corrected to $37^{\circ} \mathrm{C}$, using the correction factor of Rosenthal (7). The $\mathrm{pH}$ of urine was measured at room temperature and values were not corrected to $37^{\circ} \mathrm{C}$. The values for titratable acid were obtained by titrating all samples to a $\mathrm{pH}$ of 7.40 (rather than to the $\mathrm{pH}$ of plasma); hence the values recorded in the tables for titratable acid do not necessarily repre- 
TABLE I

Excretion of ammonium and titratable acid by the experimental and control kidneys during mannitol diuresis *

\begin{tabular}{|c|c|c|c|c|c|c|c|c|c|c|c|c|c|c|c|c|c|}
\hline \multirow{2}{*}{$\begin{array}{l}\text { Clear- } \\
\text { ance }\end{array}$} & \multirow[b]{2}{*}{ Time } & \multirow{2}{*}{$\underset{\mathrm{pH}}{\text { Plasma }}$} & \multirow{2}{*}{$\underset{\mathrm{HCO}_{3}}{\mathrm{Plasma}}$} & \multicolumn{2}{|c|}{ GFR } & \multicolumn{2}{|c|}{ Urine $\mathrm{pH}$} & \multicolumn{2}{|c|}{$\mathrm{V}$} & \multicolumn{2}{|c|}{$\mathrm{UVNH}_{4}{ }^{+}$} & \multicolumn{2}{|c|}{ UVta } & \multicolumn{2}{|c|}{$\mathrm{UVNH}_{4}{ }^{+} / \mathrm{GFR}$} & \multicolumn{2}{|c|}{ UVTA/GFR } \\
\hline & & & & $\mathrm{E}$ & $\mathrm{C}$ & $\mathrm{E}$ & $\mathrm{C}$ & $\mathrm{E}$ & $\mathrm{C}$ & $\mathbf{E}$ & $\mathbf{C}$ & $\mathrm{E}$ & $\mathrm{C}$ & $\mathrm{E}$ & C & $\mathrm{E}$ & C \\
\hline \multicolumn{18}{|c|}{$\begin{array}{ccc}\min & \mu E q / \mathrm{ml} & \mathrm{ml} / \mathrm{min} \\
\operatorname{Dog} \mathrm{NH}, \text { wt } 16.4 \mathrm{~kg} ; \text { unilateral pyelonephritis }\end{array}$} \\
\hline \multicolumn{18}{|c|}{-47.5 Sustaining infusion: $10 \%$ mannitol at $5 \mathrm{ml} / \mathrm{min}$} \\
\hline $\begin{array}{l}1 \\
2 \\
3 \\
4\end{array}$ & $\begin{array}{r}0-15 \\
15-30 \\
30-53 \\
53-70\end{array}$ & $\begin{array}{l}7.25 \\
7.24 \\
7.24 \\
7.26\end{array}$ & $\begin{array}{l}15.8 \\
13.5 \\
16.2 \\
17.1\end{array}$ & $\begin{array}{l}22.7 \\
26.3 \\
26.0 \\
27.4\end{array}$ & $\begin{array}{l}41.5 \\
44.6 \\
40.4 \\
46.8\end{array}$ & $\begin{array}{l}5.36 \\
5.32 \\
5.32 \\
5.34\end{array}$ & $\begin{array}{l}5.41 \\
5.30 \\
5.27 \\
5.25\end{array}$ & $\begin{array}{l}1.33 \\
1.51 \\
1.60 \\
1.79\end{array}$ & $\begin{array}{l}1.91 \\
2.06 \\
1.99 \\
2.43\end{array}$ & $\begin{array}{l}20.5 \\
24.0 \\
23.4 \\
25.2\end{array}$ & $\begin{array}{l}39.5 \\
41.0 \\
36.2 \\
41.3\end{array}$ & $\begin{array}{l}44.3 \\
55.9 \\
55.4 \\
61.2\end{array}$ & $\begin{array}{r}81.9 \\
92.3 \\
86.4 \\
105.5\end{array}$ & $\begin{array}{l}0.90 \\
0.91 \\
0.90 \\
0.92\end{array}$ & $\begin{array}{l}0.95 \\
0.92 \\
0.90 \\
0.88\end{array}$ & $\begin{array}{l}1.95 \\
2.12 \\
2.13 \\
2.23\end{array}$ & $\begin{array}{l}1.97 \\
2.07 \\
2.14 \\
2.25\end{array}$ \\
\hline Mean & & & & 25.6 & 43.3 & 5.34 & 5.31 & & & 23.3 & 39.5 & 54.2 & 91.5 & 0.91 & 0.91 & 2.11 & 2.11 \\
\hline
\end{tabular}

* A priming dose of $16.4 \mathrm{ml}$ of a $5 \%$ creatinine solution was administered at -48 minutes. Creatinine was infused at $7.0 \mathrm{mg} / \mathrm{minute}$ buffered sodium phosphate ( $\mathrm{pH} 7.4)$ at $160 \mu$ moles/minute, and sodium sulfate at $200 \mu$ moles $/$ minute. Four $\mathrm{g}$ of ammonium chloride was administered daily for 3 days prior to the experiment. GFR $=$ Glomerular filtration rate, $V=$ urine volume, $U V=$ excretion rate, $T A=$ titratable acid, $E=$ experimental kidney, $\mathrm{C}=$ control kidney.

sent absolute rates of acid secretion. Because of the influence of ionic strength on the second dissociation constant for phosphate $\left(\mathrm{pK}_{2}^{\prime}\right)$, differences in ionic strength between the simultaneous urine samples for the two kidneys could introduce a variable error into the titratable acid term (8). Values for phosphate $\mathrm{pK}_{2}^{\prime}$ in the separate urine samples from diseased and normal kidneys, therefore, were routinely calculated (8). However, any differences between the matching samples for the two kidneys were invariably too small to affect the comparisons. Additional details of the experimental procedures and analytic techniques have been reported previously (9).

\section{RESULTS}

Table I depicts a representative experiment on an acidotic dog receiving a mannitol infusion. Ammonium and titratable acid excretion rates for the experimental kidney were approximately 40 per cent less than the concurrent values for the control organ. However, GFR was decreased proportionately, and the excretion rates per unit of glomerular filtrate for both ammonium and titrata- ble acid were equal bilaterally. Both kidneys reabsorbed essentially all of the filtered bicarbonate. In three of the four clearance periods, the urine $\mathrm{pH}$ was slightly greater for the diseased kidney.

In Table II, results are shown for an acid-loaded dog undergoing water diuresis rather than osmotic diuresis. The decrease in GFR of the experimental kidney was somewhat more marked (relative to the control kidney) than in the preceding animal, but ammonium and titratable acid excretion rates were lowered to the same degree as GFR; hence excretion rates per unit of GFR were closely comparable for diseased and control organs. Bicarbonate reabsorption again was complete bilaterally, but the urine $\mathrm{pH}$ for the four clearance periods averaged $0.27 \mathrm{U}$ higher for the diseased kidney.

In Table III data are shown for the dog with bilateral renal disease. Although both organs had evident pathologic involvement at necropsy, the disease was more severe in the left kidney than in

TABLE II

Excretion of ammonium and titratable acid by the experimental and control kidneys during water diuresis*

\begin{tabular}{|c|c|c|c|c|c|c|c|c|c|c|c|c|c|c|c|c|c|}
\hline \multirow{2}{*}{$\begin{array}{l}\text { Clear- } \\
\text { ance }\end{array}$} & \multirow[b]{2}{*}{ Time } & \multirow{2}{*}{$\begin{array}{c}\text { Plasma } \\
\text { pH }\end{array}$} & \multirow{2}{*}{$\begin{array}{l}\mathrm{Plasma}_{\mathrm{HCO}_{3}^{-}} \\
-\end{array}$} & \multicolumn{2}{|c|}{ GFR } & \multicolumn{2}{|c|}{ Urine $\mathrm{pH}$} & \multicolumn{2}{|c|}{$\mathrm{v}$} & \multicolumn{2}{|c|}{$\mathrm{UVNH}_{4}{ }^{+}$} & \multicolumn{2}{|c|}{ UVTA } & \multicolumn{2}{|c|}{$\mathrm{UVNH}_{4}{ }^{+} / \mathrm{GFR}$} & \multicolumn{2}{|c|}{ UVTA/GFR } \\
\hline & & & & $\mathrm{E}$ & C & $\mathrm{E}$ & $\mathrm{C}$ & E & C & $\mathrm{E}$ & $\mathrm{C}$ & $\mathrm{E}$ & $\mathrm{C}$ & $\mathrm{E}$ & C & $\mathrm{E}$ & C \\
\hline \multirow{3}{*}{\multicolumn{18}{|c|}{$\begin{aligned} \text { Dog } \mathrm{Bi} \text {, wt } & 10.4 \mathrm{~kg} \text {; unilateral pyelonephritis } 26 \\
& -65 \mathrm{Water} \text { load, } 50 \mathrm{ml} / \mathrm{kg} \\
& -57 \text { Sustaining infusion: hypotonic }\end{aligned}$}} \\
\hline & & & & & & & & & & & & & & & & & \\
\hline & & & & & & & & & & & & & & & & & \\
\hline $\begin{array}{l}1 \\
2 \\
3 \\
4\end{array}$ & $\begin{array}{r}0-15 \\
15-31 \\
31-47 \\
47-64\end{array}$ & $\begin{array}{l}7.25 \\
7.25 \\
7.25 \\
7.21\end{array}$ & $\begin{array}{l}14.9 \\
16.5 \\
17.1 \\
17.2\end{array}$ & $\begin{array}{l}13.5 \\
13.1 \\
12.3 \\
13.4\end{array}$ & $\begin{array}{l}41.4 \\
3.4 \\
38.5 \\
39.8\end{array}$ & $\begin{array}{l}5.15 \\
5.15 \\
5.10 \\
5.09\end{array}$ & $\begin{array}{l}4.90 \\
4.80 \\
4.81 \\
4.83\end{array}$ & $\begin{array}{l}1.30 \\
1.19 \\
1.19 \\
1.18\end{array}$ & $\begin{array}{l}1.48 \\
1.43 \\
1.45 \\
1.50\end{array}$ & $\begin{array}{l}11.8 \\
11.2 \\
10.9 \\
11.2\end{array}$ & $\begin{array}{l}35.7 \\
34.5 \\
35.7 \\
34.5\end{array}$ & $\begin{array}{l}35.5 \\
36.4 \\
40.7\end{array}$ & $\begin{array}{l}107.4 \\
115.5 \\
129.1\end{array}$ & $\begin{array}{l}0.87 \\
0.85 \\
0.89 \\
0.84\end{array}$ & $\begin{array}{l}0.86 \\
0.90 \\
0.93 \\
0.87\end{array}$ & $\begin{array}{l}2.63 \\
2.78 \\
3.31\end{array}$ & $\begin{array}{l}2.60 \\
3.02 \\
3.35\end{array}$ \\
\hline Mean & & & & 13.1 & 39.5 & 5.12 & 4.85 & & & 11.3 & 35.1 & 37.5 & 117.3 & 0.86 & 0.89 & 2.91 & 2.99 \\
\hline
\end{tabular}

* A priming dose of $10.4 \mathrm{ml}$ of a $5 \%$ creatinine solution was administered at -48 minutes. Acid loading was performed with $7 \mathrm{~g}$ of ammonium chloride administered during the 48 hours preceding the experiment. Additional details as in Table I. 
TABLE 111

Ammonium and titratable acid excretion in serial studies on a dog with bilateral pyelonephritis *

\begin{tabular}{|c|c|c|c|c|c|c|c|c|c|c|c|c|c|c|c|c|}
\hline \multirow[b]{2}{*}{ Exp. } & \multirow{2}{*}{$\begin{array}{l}\text { Plasma } \\
\text { pH }\end{array}$} & \multirow{2}{*}{$\begin{array}{l}\text { Plasma } \\
\mathrm{HCO}_{3}^{-}\end{array}$} & \multicolumn{2}{|c|}{ GFR } & \multicolumn{2}{|c|}{ Urine $\mathrm{pH}$} & \multicolumn{2}{|c|}{ V } & \multicolumn{2}{|c|}{$\mathrm{UVNH}_{4}{ }^{+}$} & \multicolumn{2}{|c|}{ UVtA } & \multicolumn{2}{|c|}{$\mathrm{UVNH}_{4}+/ \mathrm{GFR}$} & \multicolumn{2}{|c|}{ UVtA/GFR } \\
\hline & & & $\mathrm{E}$ & C & $\mathrm{E}$ & C & $E$ & $\mathrm{C}$ & $\mathrm{E}$ & C & $\mathrm{E}$ & $\mathrm{C}$ & $\mathrm{E}$ & C & $\mathrm{E}$ & C \\
\hline & & $\mu E q / m l$ & \multicolumn{2}{|c|}{$m l / \min$} & & & \multicolumn{2}{|c|}{$m l / \min$} & \multicolumn{2}{|c|}{$\mu E q / \min$} & \multicolumn{2}{|c|}{$\mu E q / \min$} & \multicolumn{2}{|c|}{$\mu E q / m l$} & \multicolumn{2}{|c|}{$\mu E q / m l$} \\
\hline $\begin{array}{l}1 \\
2 \\
3 \\
4\end{array}$ & $\begin{array}{l}7.30 \\
7.19 \\
7.15 \\
7.25\end{array}$ & $\begin{array}{l}15.7 \\
14.2 \\
17.4 \\
14.1\end{array}$ & $\begin{array}{l}14.3 \\
20.9 \\
21.0 \\
23.1\end{array}$ & $\begin{array}{l}30.1 \\
43.4 \\
51.0 \\
44.4\end{array}$ & $\begin{array}{l}5.89 \\
5.70 \\
6.00 \\
6.25\end{array}$ & $\begin{array}{l}5.89 \\
5.68 \\
5.94 \\
6.17\end{array}$ & $\begin{array}{l}0.89 \\
1.51 \\
1.72 \\
2.20\end{array}$ & $\begin{array}{l}1.94 \\
2.90 \\
3.54 \\
3.65\end{array}$ & $\begin{array}{r}5.8 \\
29.6 \\
10.4 \\
12.1\end{array}$ & $\begin{array}{l}12.3 \\
55.5 \\
48.9 \\
24.4\end{array}$ & $\begin{array}{l}18.0 \\
34.2 \\
55.8 \\
47.8\end{array}$ & $\begin{array}{r}38.3 \\
68.8 \\
130.5 \\
91.9\end{array}$ & $\begin{array}{l}0.41 \\
1.41 \\
0.48 \\
0.52\end{array}$ & $\begin{array}{l}0.40 \\
1.27 \\
0.86 \\
0.55\end{array}$ & $\begin{array}{l}1.27 \\
1.57 \\
2.67 \\
2.05\end{array}$ & $\begin{array}{l}1.28 \\
1.62 \\
2.57 \\
2.07\end{array}$ \\
\hline
\end{tabular}

* Each value is the mean of 3 to 4 individual clearance periods. The experiments were performed from 1 to 2 weeks apart. Four $\mathrm{g}$ of $\mathrm{NH} \mathrm{H}_{4} \mathrm{Cl}$ was administered daily for 3 to 5 days before each study.

the right. In all four studies performed on this animal, values for titratable acid excretion per unit of GFR were essentially equal bilaterally, and in three of the four studies values for ammonium excretion per unit of GFR were virtually the same for the two kidneys. In the third experiment, however, ammonium excretion was lower for the left kidney. Urine $\mathrm{pH}$ values tended to be slightly higher for the kidney with the more extensive disease.

In Table IV the results are shown for an animal studied during sodium bicarbonate infusion. For both kidneys the urine was alkaline and hence contained no titratable acid. Ammonium excretion, although small in amount in consequence of the high urinary $\mathrm{pH}$ values, had the same value per unit of GFR for the experimental and control kidneys. The diseased kidney excreted a somewhat greater amount of bicarbonate per unit of GFR than did the normal organ, an observation which has been confirmed and extended in separate studies (10).

Group data for all experiments are shown in Figures 1 and 2. Each point in the graphs repre- sents an individual clearance period. In Figure 1, excretion rates of ammonium per unit of GFR for the experimental kidneys have been plotted against corresponding values for the control organs. The points are grouped about the line of unity, reflecting the fact that in 14 of 16 experiments, values were essentially equal bilaterally. The five points showing appreciably lower values for the experimental kidneys were obtained from the third experiment performed on the animal with bilateral disease. However, in the first, second, and fourth experiments on the same animal, values were equal bilaterally. In Figure 2 a similar plot has been made for titratable acid excretion. Again, the points lie close to the line of unity. No significant difference in titratable acid excretion per unit of filtrate was found in any of the acid-loaded animals ( $\mathrm{p}$ in a paired $t$ test always $>0.2$ ).

\section{DISCUSSION}

These studies demonstrate a rather striking preservation of acid-secreting capacity in the functioning nephrons of the experimentally diseased kidney. In 12 of 14 experiments on acid-loaded

TABLE IV

Ammonium excretion during sodium bicarbonate infusion *

\begin{tabular}{|c|c|c|c|c|c|c|c|c|c|c|c|c|c|c|c|c|c|}
\hline \multirow{2}{*}{$\begin{array}{l}\text { Clear- } \\
\text { ance } \\
\text { period }\end{array}$} & \multirow[b]{2}{*}{ Time } & \multirow{2}{*}{$\underset{\mathrm{pH}}{\text { Plasma }}$} & \multirow{2}{*}{$\underset{\mathrm{HCO}_{3}^{-}}{\text {Plasma }}$} & \multicolumn{2}{|c|}{ GFR } & \multicolumn{2}{|c|}{ V } & \multicolumn{2}{|c|}{ Urine $\mathrm{pH}$} & \multicolumn{2}{|c|}{$\mathrm{UVNH}_{4}{ }^{+}$} & \multicolumn{2}{|c|}{$\mathrm{UVNH}_{4}+/ \mathrm{GFR}$} & \multicolumn{2}{|c|}{$\mathrm{UVHCO}_{3}^{-}$} & \multicolumn{2}{|c|}{$\underset{\mathrm{GFR}^{-}}{\mathrm{UVHCO}_{3}-/}$} \\
\hline & & & & $\mathrm{E}$ & $\mathrm{C}$ & $\mathrm{E}$ & $\mathrm{C}$ & $\mathrm{E}$ & C & $\mathrm{E}$ & $\mathrm{C}$ & $\mathrm{E}$ & V & $\mathrm{E}$ & $\mathrm{C}$ & $\mathbf{E}$ & C \\
\hline \multicolumn{18}{|c|}{ Dog Sh, wt $17.3 \mathrm{~kg}$; unilateral pyelonephritis } \\
\hline \multicolumn{18}{|c|}{-60 Priming dose of $17.3 \mathrm{ml}$ of $5 \%$ solution of creatinine } \\
\hline \multicolumn{18}{|c|}{-59 Sustaining infusion: $12.5 \%$ mannitol and $0.13 \mathrm{~N} \mathrm{NaHCO}_{3}$ at $5 \mathrm{ml} / \mathrm{min}$} \\
\hline $\begin{array}{l}1 \\
2 \\
3 \\
4\end{array}$ & $\begin{array}{r}0-16 \\
16-34 \\
34-49 \\
49-59\end{array}$ & $\begin{array}{l}7.39 \\
7.40 \\
7.39 \\
7.42\end{array}$ & $\begin{array}{l}26.4 \\
28.2 \\
27.2 \\
29.6\end{array}$ & $\begin{array}{l}22.3 \\
19.6 \\
22.4 \\
22.2\end{array}$ & $\begin{array}{l}45.1 \\
40.9 \\
49.5 \\
45.0\end{array}$ & $\begin{array}{l}5.20 \\
5.06 \\
5.99 \\
5.73\end{array}$ & $\begin{array}{l}5.46 \\
5.30 \\
6.83 \\
6.43\end{array}$ & $\begin{array}{l}7.39 \\
7.31 \\
7.52 \\
7.43\end{array}$ & $\begin{array}{l}7.49 \\
7.52 \\
7.57 \\
7.49\end{array}$ & $\begin{array}{l}4.11 \\
3.09 \\
2.76 \\
2.46\end{array}$ & $\begin{array}{l}8.79 \\
6.41 \\
6.56 \\
4.89\end{array}$ & $\begin{array}{l}0.18 \\
0.16 \\
0.12 \\
0.11\end{array}$ & $\begin{array}{l}0.19 \\
0.16 \\
0.13 \\
0.11\end{array}$ & $\begin{array}{l}129 \\
134 \\
177 \\
176\end{array}$ & $\begin{array}{l}191 \\
196 \\
250 \\
248\end{array}$ & $\begin{array}{l}5.78 \\
6.82 \\
7.89 \\
7.92\end{array}$ & $\begin{array}{l}4.24 \\
4.79 \\
5.05 \\
5.52\end{array}$ \\
\hline Mean & & & & 21.6 & 45.1 & 5.50 & 6.0 & 7.41 & 7.52 & 3.11 & 6.67 & 0.14 & 0.15 & 154 & 221 & 6.94 & 4.90 \\
\hline
\end{tabular}

* Creatinine was infused at $7.0 \mathrm{mg} /$ minute throughout. 


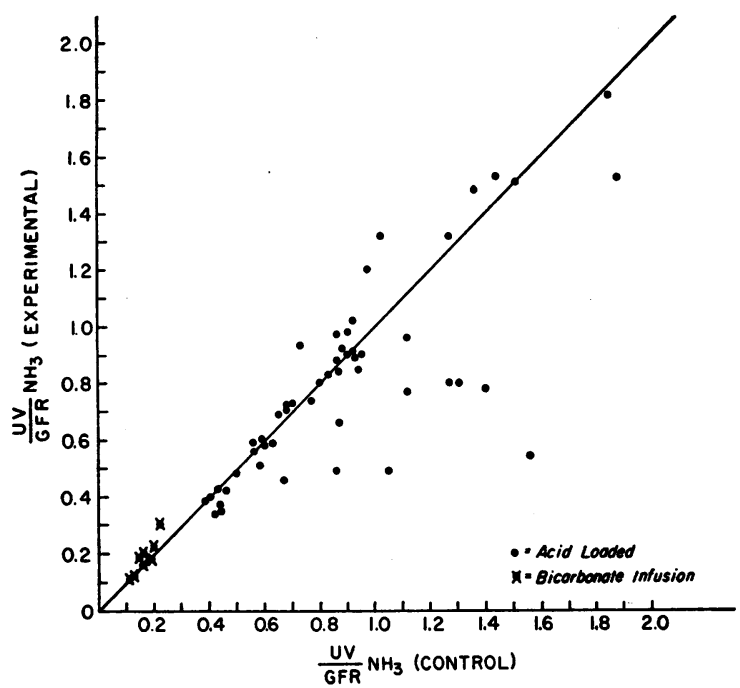

Fig. 1. Relationship BetWeEn AMMONIUM EXCRETION PER UNIT OF GFR IN THE EXPERIMENTAL AND CONTROL KIDNEYS.

dogs, and in the two studies on dogs which did not receive an acid load and which received sodium bicarbonate, values for ammonium excretion per unit of glomerular filtrate were equal for the two kidneys. Equality of titratable acid excretion per unit of filtrate was observed in all experiments on acidotic dogs. Finally, in the presence of metabolic acidosis and a decreased plasma bicarbonate concentration, the diseased kidneys reabsorbed essentially all of the filtered bicarbonate. Thus, both total hydrogen ion secretion (estimated as ammonium excretion + titratable acid excretion + bicarbonate reabsorption), and net hydrogen ion excretion (estimated as ammonium excretion $+\mathrm{ti}$ tratable acid excretion - bicarbonate excretion) had the same values per unit of glomerular filtrate in experimental and control kidneys under conditions evoking high rates of acid excretion. In view of the fact that the transfer of hydrogen ions into the tubular fluid probably occurs along much of the length of the nephron (11), these data are in concert with previous observations indicating that the residual nephrons of the experimentally diseased kidney retain a high degree of functional organization (12). ${ }^{1}$

1 It is implicit in this conclusion that factoring by GFR tends to correct for the differences in the number of functioning nephrons between the experimental and control kidneys. The basis for this assumption has been discussed in a previous communication (13).
It is of interest to compare the present observations with the acid-secreting capacity of the patient with chronic uremia. In most forms of chronic Bright's disease, there are four characteristic events which are relevant to this comparison. 1) As already noted, once acidosis evolves, hydrogen ion concentration of extracellular fluid may remain constant for long periods of time. 2) Daily rates of ammonium excretion, as well as the increments in excretion following an exogenous acid load, are decreased in relation to normal subjects (14-18). 3) Daily rates of titratable acid excretion may be either less than $(16,18)$ or greater than (19) in normal subjects; but the excretion of titratable acid does not appear to be rate limited in the same manner as is ammonium excretion. 4) Urinary $\mathrm{pH}$ values typically are below 5.5 and often are below $5.0(14,15,18,19)$.

The capacity to maintain stable hydrogen ion concentrations in the extracellular fluid despite random fluctuations in the metabolic load of hydrogen ion would support the view that there also is an orderly pattern of proton excretion in the surviving nephrons of the uremic patient. However, the fact that the arterial $\mathrm{pH}$ values are held constant at a lower than normal level indicates that, in the presence of a markedly diminished population of nephrons, metabolic acidosis is a requisite for continuing high rates of net proton excretion per nephron. The decrease in total am-

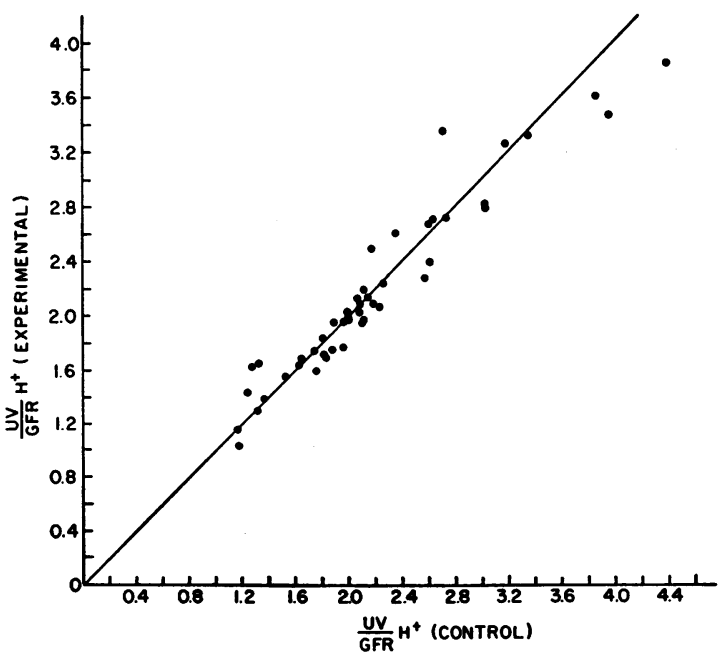

Fig. 2. Relationship Between titratable acid exCRETION (UV $\mathrm{H}^{+} / \mathrm{GFR}$ ) IN EXPERIMENTAL AND CONTROL KIDNEYS. 
monium excretion in uremic man was also observed in the diseased kidneys of the experimental animals. In the absence of renal disease, in both man and dog, ammonium excretion will increase markedly from basal rates in association with metabolic acidosis; but in both species there is an upper limit of excretion which persists despite the presence of maximally acidified urine $(20,21)$. Presumably, the availability of glutamine and other substrates, or the activity of the glutaminases and associated enzymes involved in the renal production of ammonia, or both, could represent the ratelimiting steps. In view of this rate limitation, an absolute decrease in the number of functioning nephrons must be associated with a concomitant decrease in the maximal rates of total ammonia excretion even if excretion per nephron remains normal. The fact that ammonium excretion per unit of glomerular filtrate was essentially equal in the two kidneys of the present experimental animals would suggest that the rate-limiting events were closely comparable in the functioning nephrons of both organs. Moreover, studies of Wrong and Davies (18) indicate that a similar explanation is tenable in uremic man. Thus, after the administration of ammonium chloride $(0.1 \mathrm{~g}$ per $\mathrm{kg}$ ), the values for ammonium excretion per unit of GFR were in the same range in a group of patients with chronic progressive renal disease as those in normal subjects. Wrong and Davies alluded to the possibility that the limitation in total ammonium excretion might reflect the decrease in the number of functioning nephrons. It is possible, therefore, to account for the restriction in total ammonium excretion (as opposed to ammonium excretion per unit of GFR) on the basis of a reduction in the population of residual nephrons without necessarily postulating the existence of a specific defect in the renal tubules.

The excretion of titratable acid is limited by the availability of hydrogen ions in the renal tubular epithelial cell water, by the capacity to transfer these hydrogen ions into the tubular fluid, by the minimum urinary $\mathrm{pH}$, by the average rate of excretion of phosphate buffer per nephron, and finally by the total number of nephrons. The present observations suggest that the lower rates of total titratable acid excretion by the experimentally diseased than by the contralateral kidneys relate principally to the decrease in nephron population in the involved kidneys rather than to any acquired abnormality in the acid-secreting mechanism. There is an increasing body of evidence to support the same explanation for the chronically diseased kidney of uremic man. The $\mathrm{pK}^{\prime}$ for the major urinary buffer, phosphate, is approximately 6.8 and, as pointed out by Schwartz, Hall, Hays and Relman (17), the frequent ability of the acidotic uremic patient to excrete urine with a $\mathrm{pH}$ of 5.5 or less indicates that, for any given level of buffer excretion, the titratable acid excretion is maximal or near maximal. Furthermore, it has recently been shown by Hall (22) and by Gonick, Kleeman, and Maxwell (23) that patients with chronic renal disease and spontaneous or induced acidosis could be made to increase their titratable acid excretion from their apparent maximal rates by phosphate loading. In association with the higher rates of buffer excretion, urine $\mathrm{pH}$ values remained at their previous minimum levels (22); hence, despite the increase in absolute rate of acid excretion, the diseased kidneys were capable of maintaining maximal titratable acid excretion for the existing conditions. Thus, in both dog and man, lower than normal values for titratable acid excretion by the chronically diseased kidney do not appear to be imposed by a limitation in the availability of intracellular hydrogen ions, or by a defect in the system subserving the transfer of these hydrogen ions into the tubular fluid. Rather it would seem that the total amount of buffer and the total number of functioning nephrons determine the maximal rate of titratable acid excretion.

\section{SUMMARY}

The patterns of ammonium and titratable acid excretion were investigated in dogs with experimental renal disease. In the majority of experiments, one kidney in the experimental model was maintained free of disease so as to permit comparison of the acidifying capacity of a diseased kidney with that of an intact kidney subsisting in the same environment. In addition, several experiments were performed on an animal with bilateral disease of different severity in the two kidneys. Exogenous metabolic acidosis was produced by administering ammonium chloride for 1 to 5 days preceding clearance measurements. Excretion of 
both ammonium and titratable acid per unit of glomerular filtrate was closely comparable in experimental and control kidneys and bicarbonate reabsorption was virtually complete bilaterally. Thus, both total hydrogen ion secretion and net hydrogen ion excretion per unit of glomerular filtrate remained equal in experimental and control organs. These results indicate that under conditions evoking high rates of acid excretion, there is an organized pattern of proton transfer in the functioning nephrons of the experimentally diseased kidney of the dog. The relevance of these data to the interpretation of acidifying capacity in the human with chronic uremic acidosis is considered in the discussion.

\section{REFERENCES}

1. Bricker, N. S., Dewey, R. R., and Lubowitz, H. Studies in experimental pyelonephritis: Simultaneous and serial investigation of a pyelonephritic and intact kidney in the same animal. Clin. Res. 1958, 6, 292.

2. Bricker, N. S., Stokes, J. M., Lubowitz, H., Dewey, R. R., Bernard, H. R., and Hartroft, P. M. Experimentally induced permanent unilateral renal disease in dogs. J. Lab. clin. Med. 1958, 52, 571.

3. Desautels, R. E. Hemisection of the bladder for the collection of separate urine samples. Surg. Gynec. Obstet. 1957, 105, 767.

4. Bonsnes, R. W., and Taussky, H. H. On the colorimetric determination of creatinine by the Jaffe reaction. J. biol. Chem. 1945, 158, 581.

5. Van Slyke, D. D., and Neill, J. M. The determination of gases in blood and other solutions by vacuum extraction and manometric measurement. I. J. biol. Chem. 1924, 61, 523.

6. Nathan, D. G., and Rodkey, F. L. A colorimetric procedure for the determination of blood ammonia. J. Lab. clin. Med. 1957, 49, 779.

7. Rosenthal, T. B. The effect of temperature on the $\mathrm{pH}$ of blood and plasma in vitro. J. biol. Chem. 1948, 173, 25.

8. Schwartz, W. B., Bank, N., and Cutler, R. W. The influence of urinary ionic strength on phosphate $\mathrm{pK}_{2}^{\prime}$ and the determination of titratable acid. $\mathrm{J}$. clin. Invest. 1959, 38, 347.

9. Bricker, N. S., Straffon, R. A., Mahoney, E. P., and Merrill, J. P. The functional capacity of the kid- ney denervated by autotransplantation in the dog. J. clin. Invest. 1958, 37, 185.

10. Morrin, P. A. F., Gedney, W. B., Newmark, L. N., and Bricker, N. S. Bicarbonate reabsorption in the dog with experimental renal disease. J. clin. Invest. 1962, 41, 1303.

11. Gottschalk, C. W., Jassiter, W. E., and Mylle, M. Localization of urine acidification in the mammalian kidney. Amer. J. Physiol. 1960, 198, 581.

12. Bricker, N. S., Morrin, P. A. F., and Kime, S. W., Jr. The pathologic physiology of chronic Bright's disease. An exposition of the "intact nephron hypothesis." Amer. J. Med. 1960, 28, 77.

13. Bricker, N. S., Kime, S. W., Jr., Morrin, P. A. F., and Orlowski, T. The influence of glomerular filtration rate, solute excretion and hydration on the concentrating mechanism of the experimentally diseased kidney in the dog. J. clin. Invest. 1960, $39,864$.

14. Henderson, L. J., and Palmer, W. W. On the several factors of acid excretion in nephritis. J. biol. Chem. 1915, 21, 37.

15. Palmer, W. W., and Henderson, L. J. A study of the several factors of acid excretion in nephritis. Arch. intern. Med. 1915, 16, 109.

16. Van Slyke, D. D., Linder, G. C., Hiller, A., Leiter, L., and McIntosh, J. F. The excretion of ammonia and titratable acid in nephritis. J. clin. Invest. 1926, 2, 255.

17. Schwartz, W. B., Hall, P. W., III, Hays, R. M., and Relman, A. S. On the mechanism of acidosis in chronic renal disease. J. clin. Invest. 1959, 38, 39.

18. Wrong, O., and Dayies, H. E. F. The excretion of acid in renal disease. Quart. J. Med. 1959, 28, 259.

19. Briggs, A. P., Waugh, W. H., Harms, W. S., and Findley, T. Pathogenesis of uremic acidosis as indicated by urinary acidification on a controlled diet. Metabolism 1961, 10, 749.

20. Sartorius, O. W., Roemmelt, J. C., and Pitts, R. F. The renal regulation of acid-base balance in man. IV. The nature of the renal compensations in ammonium chloride acidosis. J. clin. Invest. 1949, 28, 423.

21. Pitts, R. F. Renal excretion of acid. Fed. Proc. 1948, 7, 418.

22. Hall, P. W., III. Factors limiting hydrogen ion excretion in renal disease (abstract). J. Lab. clin. Med. 1961, 58, 823.

23. Gonick, H. C., Kleeman, C. R., and Maxwell, M. H. Importance of buffer availability in the impaired acid excretion of chronic renal disease. Clin. Res. 1962, 10, 123. 